\title{
Tipo textual injuntivo: exemplos em revistas impressas de negócios
}

Cleonice MEN (USP)

RESUMO: Ao considerar os gêneros textuais reportagem de capa e encarte, veiculados em revistas da esfera de sentido negócios empresariais, este artigo visa a mostrar como se apresenta a transmissão de um saber-fazer, dado por meio do tipo textual injuntivo, colaborando, no discurso, para um universo do poder e saber estabilizado.

PALAVRAS-CHAVE: discurso empresarial; revistas impressas; gênero textual; tipo textual.

ABSTRACT: By considering the textual genres cover report and insert, this article aims at showing how a knowing-to-do transmission is presented in printed magazines engaged in the sphere of business by means of a textual type: the injunctive one, which collaborates, on the discourse, in a stable being-able and knowing universe.

KEY WORDS: corporate discourse; printed magazines; textual genre; textual type. 


\section{Preliminares}

Tomam-se, para este artigo, o texto constituinte reportagem de capa veiculado na revista $E X A M E$, edição 765 , de $1^{\circ}$ de maio de 2002 , e os encartes ${ }^{1}$ pares da revista VendaMais, inseridos na edição 147, de julho de 2006, textos considerados materializações de gêneros textuais. A revista EXAME, da Editora Abril, tem circulação quinzenal e temática de negócios e economia. A revista VendaMais, da Editora Quantum, é publicação técnica mensal destinada à área de administração em vendas e marketing.

A reportagem traz como título, na capa, "O Manual do Bom Chefe". Na abertura, nas pp. 40-41, aparece o título "Quer ser um bom chefe?. Como desdobramento dessa reportagem, outra é seqüencialmente veiculada na p. 50, intitulada "Múltipla escolha" e subintitulada "Descobrimos uma receita de bom chefe! Não, duas. Não, três. Não...". Os encartes trazem como títulos: "Como vender bem" (encarte formato pôster - anexos, Fig. 2) e "Dicas de Bolso - VendaMais Hoje - Serviços" (encarte formato sanfona - anexos, Fig. 3 e Fig. 4$)^{2}$.

\section{Referenciais teóricos}

As revistas, por pertencerem à mídia impressa, abrigam enunciados na materialidade física (o papel), o que determina o suporte material. Em dada esfera de atividade social discursiva própria - a de administração/negócios empresariais constituem suportes específicos do discurso jornalístico. Considera-se que essas mídias impressas, por trazerem conteúdos consoantes à esfera social em que atuam, têm uma instância de recepção delimitada, um destinatário-alvo no contrato de comunicação proposto. Esse destinatário é considerado receptivo, isto é, está num espaço de recepção no qual "se encontra o destinatário ideal - aquele que em comunicação se designa como alvo - que é imaginado pela instância midiática como suscetível de perceber os efeitos visados por ela. Esse espaço não é mais do que o lugar dos "efeitos esperados"” (Charaudeau, 2006: 26).

Temos uma comunicação autocentrada, destinada e de plena interação, voltada exclusivamente para leitores específicos, considerados imagens pressupostas de sujeitos semióticos. Esses sujeitos (enunciatários-leitores) são pré-selecionados por um

\footnotetext{
${ }^{1}$ Considera-se, para esse verbete, a entrada 3 do Dic. Houaiss (2004): "GRAF. Operação de inserir (em uma publicação) uma revista, um folheto, etc., ger. de cor ou de aspecto gráfico diferente, que constitui uma separata de matérias especiais ou puramente publicitária".

${ }^{2}$ Sanfona: "Termo que designa qualquer impresso (geralmente folheto ou encarte) que apresenta dobras repetidas, como um fole de sanfona. Impresso em feitio sanfonado, que o leitor vai desdobrando para ler, como quem abre as páginas de um livro" (Rabaça e Barbosa, 1978: 526).
} 
enunciador com uma imagem já formada: uma imagem positiva. O enunciador sabe que esse seu enunciatário está predisposto a querer-fazer, interpretar a informação transmitida, já que "a eficácia do discurso ocorre quando o enunciatário incorpora o éthos do enunciador. Essa incorporação pode ser harmônica, quando éthos e pathos ajustam-se perfeitamente" (Fiorin, 2004: 8). Aprofunda o autor: "O pathos não é a disposição real do auditório, mas a de uma imagem que o enunciador tem do enunciatário. Essa imagem estabelece coerções para o discurso" (Fiorin, 2004: 5).

No nível narrativo do percurso gerativo de sentido, temos, assim, um destinador-manipulador dado como atualizado, competente: tem o saber e o poder-fazer.

Maingueneau (2002: 43) complementa ao afirmar que "a competência comunicativa consiste essencialmente em se comportar como convém nos múltiplos gêneros de discursos: é antes de tudo uma competência genérica". Ao tratar de gêneros, Fiorin (2004: 2) diz que "são organizações relativamente estáveis caracterizadas por uma temática, uma forma composicional e um estilo".

As linguagens verbais que compõem esses gêneros, materializados em atos comunicativos inseridos em esferas de atuação discursivas específicas, acham-se presentes em seqüências textuais dominantes, que determinam tipos textuais predominantes. Fiorin (2004: 5) esclarece: "Os tipos [textuais] são construções textuais que apresentam determinadas características lingüísticas. São bem poucos os tipos textuais: o narrativo, o descritivo, o expositivo, o opinativo, o argumentativo e o injuntivo". E complementa: "Quando dizemos que o tipo textual é uma categoria mais geral do que o gênero, o que queremos dizer é que os gêneros fazem uso dos tipos na sua composição. Assim, um mesmo tipo é utilizado por diferentes gêneros" (Fiorin, 2004: 5). Gênero e tipo, portanto, complementam-se na produção textual verbal.

Considera-se, especialmente para este artigo, o tipo textual injuntivo, já que o gênero reportagem em análise traz seqüências textuais dominantes exemplares desse tipo; os encartes, observa-se, o tem como predominante. Traços de injunção podem ser depreendidos nesses textos porque "os textos injuntivos, embora se apresentem como uma seqüência de injunções, na verdade, transmitem um saber sobre como realizar alguma coisa, expõem um plano de ação para atingir determinado objetivo" Fiorin (2004, p. 13). Assim, trazem dicas a seguir. Desse modo, ao considerar o tipo textual injuntivo, há que deter-se mais nos aspectos sintáticos, tempos verbais e na organização do conteúdo, os quais, ao informar, ditam regras de como fazer.

\section{Análises}

\subsection{Gênero textual reportagem de capa}

A reportagem de capa de uma revista impressa é um gênero textual cujo conteúdo remete ao grau mais alto de importância, uma vez que veicula tema à altura de circular nesse espaço de prioridade. A teoria da comunicação pontua que esse gênero privilegia o discurso jornalístico-informativo. Acrescente-se que, se quisermos apoio dos tipos textuais, diremos que o jornalismo informativo privilegia o texto narrativo, no qual são inseridas sequiências argumentativas pontuais. Esse texto, contudo, na íntegra e 
posto internamente na revista $E X A M E$, é híbrido e costuma trazer seqüências textuais de outros tipos textuais.

Falemos, primeiramente, da comunicação de plena interação entre sujeitos. Além da pergunta retórica do narrador presente na capa "Você quer ser um deles?", no título de abertura dessa mesma reportagem, nas pp. 40-41, encontramos outra: "Quer ser um bom chefe?". Essas perguntas "convidam" diretamente o narratário-leitor para ser (tornar-se) bom chefe: "Você quer...?" "Quer ser...?". Configura-se, assim, o diálogo encetado entre sujeitos, o que marca o efeito discursivo de proximidade. Esses sujeitos semióticos, inseridos numa instância de comunicação própria, detêm valores partilhados no ato comunicativo e no mundo.

A aproximação, com o efeito de subjetividade, é marcada, ainda, com o eu (nós: $1^{a}$ pessoa do plural) que se desvela explicitamente para o $t u$. Temos, desse modo, o narrador que invoca e dialoga explicitamente com o narratário-leitor no ato comunicativo. Trazemos o fragmento: "No fim das contas, desculpe-nos, leitor, não encontramos um chefe-padrão. Não é que não haja receita. É que há infinitas receitas. Ainda bem" (EXAME, $1 \% / 05 / 2002$, p. 49).

Do subtítulo dessa reportagem: "Não, não vamos ensinar o caminho das pedras. Mas podemos ajudá-lo a tirar algumas pedras do caminho", ressaltam-se as figuras "podemos" e "ajudá-los" e vê-se posicionada a voz discursiva de um sujeito que diz explicitamente que pode ajudar o outro a saber como fazer para tornar-se bom chefe. Na voz discursiva do enunciador, o crer saber e o poder-fazer se juntam no contrato fiduciário prévio estabelecido.

Detemo-nos na análise das seqüências textuais dominantes na reportagem, que apresentam o tipo textual injuntivo. No próprio título da capa "O Manual do Bom Chefe" está a marca de texto injuntivo, já que se trata de um manual, isto é, um texto feito para ditar regras de como fazer para tornar-se bom chefe. Dentre as configurações expostas por Discini (cf. 2005: 192-193) sobre manual, extraímos a primeira, que o define como um "conjunto de noções práticas sobre procedimentos a ser cumpridos para a boa realização de uma tarefa". Tais noções práticas serão "ensinadas" pelo enunciador a um enunciatário-leitor predisposto a aprendê-las.

Entre as pp. 40 e 49 da reportagem, há quadros isolados, numerados de 1 a 9. Esses quadros têm por título "O ciclo do chefe". Assim, temos: 1. Sintonia com a empresa; 2. Como contratar; 3. Como manter - e desenvolver - talentos; 4. Como conviver com os funcionários; 5. Como montar a equipe; 6. Como motivar; 7. Como demitir; 8. Como dar resultado; 9. Como saber a hora de ir embora. Notemos a recorrência de uso do termo como nesses quadros - um total de 8 -, caracterizando profusamente um texto que dita regras de como fazer, de tipo injuntivo predominante, portanto. Fiorin diz que, no texto injuntivo, as ações a realizar em sequiência para atingir determinado objetivo "são apresentadas no imperativo ou em forma verbal com valor de imperativo" (2004:14).

Trazemos o quadro "2. Como contratar" (anexos, Fig. 1) para observar o discurso de tom imperativo. Nele, em tópicos seqüenciais, aparecem 23 verbos no imperativo, a maioria iniciando orações, o que corrobora o dito de como fazer. É desse modo que o texto norteia o leitor para a interpretação de regras a cumprir. Citemos aqui tais verbos: "conheça; descreva; fale; desenhe; entreviste; siga; varie; descreva; 
pergunte; habitue-se; cheque; evite; reserve; não entre; transmita; verifique; telefone; avise; negocie; jamais ultrapasse; nunca cubra; envie; agradeça".

Da reportagem seqüencial, com início na p. 50, de título: "Múltipla escolha" e subtítulo "Descobrimos uma receita de bom chefe! Não, duas. Não, três. Não...", ela é, do mesmo modo, marca expressa de texto injuntivo programador, confirmado também com a figura citada: receita. Um bom chefe, conforme se depreende da reportagem, é aquele que partilha quereres, deveres, poderes e saberes com seus funcionários. Por isso, pela mão do destinador-manipulador chega a receita de como fazer para tornar-se bom chefe e isso (o ato de tornar-se) é tomado pelo destinatário de modo eufórico, já que este quer ser um bom chefe, tal como o destinador o vê: um sujeito competente para interpretar, seguir a receita dada. Afirma Discini (2005: 188) que, "para realizar-se como aquele que age, o sujeito deverá antes saber e poder fazer algo. Com isso terá a própria competência garantida para a performance".

Ao considerar as classes tipológicas de manipulação, com sujeitos denominados no nível narrativo do percurso gerativo de sentido, temos um destinadormanipulador (S1) que vai manipular o destinatário - (S2) por tentação e sedução, pelo poder e pelo saber fazer. Nessa manipulação, facilitada pela instância de produção segmentada, circulam a imagem e valores positivos. No caso da manipulação por tentação, o objeto-valor oferecido é o saber, um objeto modal.

Assim se apresenta o ato de manipulação que considera a imagem positiva do destinador (S1) para com seu destinatário-alvo (S2):

Tentação: Se você seguir a receita aqui prescrita, será recompensado, terá mais saber para tornar-se um bom chefe. ainda, não é?

Sedução: Você, que já é um bom profissional, ao ter mais saber, será melhor

Consideramos, desse modo, que ambos os sujeitos na relação de manipulação detêm competência modal, possuidores que são de poder, saber e querer. Consideramos, ainda, que diz respeito a uma relação assimétrica, já que o destinador, que remete ao enunciador, sabe mais que seu enunciatário-leitor (destinatário-alvo), este que, entretanto, está propenso a aprender; e é por isso que o enunciador pode prescrever, ditar regras de como fazer. O destinatário-alvo é um sujeito (do fazer) do mundo corporativo, ele quer fazer, tornar-se bom chefe.

\subsection{Gênero textual encartes}

Encarte pôster (anexos, Fig. 2);

Encarte dicas de bolso, de formato sanfona (anexos, Fig. 3 e Fig. 4).

Os textos, materializações de gêneros textuais encartes, oferecem dicas a seguir: constituem parte integrante da edição, dados como englobados no englobante. Comprovam isso as "chamadas" na capa dessa edição: a) para a leitura da reportagem de capa da revista VendaMais, edição 147, de título "Serviços - como vender o que o cliente não vê - Pág. 26" (anexos, Fig. 5) e b) o desenho redondo, acima do logotipo VendaMais, de fundo cinza com enunciado em branco "GRÁTIS - pôster e brinde de 
bolso". Assim, esses gêneros encontram-se circundados na mesma esfera de sentido: a de atividade institucionalizada jornalístico-empresarial.

Os encartes são textos que trazem informações consideradas privilegiadas. Destacados e destacáveis nas publicações, podem veicular "anúncio, matéria especial, ilustrações, mapas, informações, etc.” (Rabaça e Barbosa, 1978: 234).

A cromática nesses textos é merecedora de análise como efeito de sentido. $\mathrm{Na}$ capa da revista, predomina o verde-limão brilhante, em harmonia com o branco, preto e cinza, que se alternam para o verbal, fundo das tarjas com enunciados, assemelhando-se aos encartes: dicas em formato de sanfona e pôster. Esses efeitos são produzidos no e depreensíveis do texto. Temos, igualmente, como fundo dos encartes, o verde-limão brilhante. É uma cor bastante chamativa, considerada até hiperbólica.

$\mathrm{O}$ encarte pôster pode ser considerado de tamanho grande se comparado à revista e a seu par, o dicas de bolso: mede $42 \mathrm{~cm}$ de largura e $29,7 \mathrm{~cm}$ de altura. Esse texto traz formato original e arranjos planejados na forma composicional. No título, está presente o vocábulo como. "Como vender bem" é grafado na cor branca. Excetuando as letras iniciais, igualmente grafadas em branco, que formam a palavra serviços na vertical, o restante dos enunciados é escrito em preto (anexos, Fig. 2). No que diz respeito às letras iniciais, arranjadas na vertical para formar o vocábulo "serviços", a exceção é para o "c-cedilha", substituído pela vogal "a", já que não existem palavras em português iniciando-se com essa letra.

A par do quadro da reportagem (anexos, Fig. 1), trazemos, deste gênero textual encarte-pôster, os verbos no imperativo, num total de onze e que traz, relembremos, o título "Como vender bem": sonhe; estude; analise; seja (um especialista); reveja; vigie; incentive; use; ouça; sorria; seja (simpático).

Nota-se o tratamento informal no último enunciado do encarte: "Em serviços, você é a imagem do que vende". O narrador trata o narratário-leitor por você, o que marca, como recorrência, a aproximação, a interação mais subjetiva, tal como observado no gênero reportagem.

A palavra como, ratificamos, remete a uma voz discursiva que se pauta por traços de um tipo textual - o injuntivo -, que vai "ensinar", especialmente ao grupo de profissionais de vendas, como "vender bem serviços".

$\mathrm{O}$ encarte dicas de bolso, de formato sanfona, é de tamanho pequeno, se comparado ao encarte pôster, medindo $5,6 \mathrm{~cm}$ de largura x 8,6 cm de altura (anexos, Fig. 3 e Fig. 4). É um texto adequado para levar no bolso e consultar regularmente.

Em consonância com o encarte pôster, traz as mesmas nuanças de cores: fundo verde com enunciados grafados em branco e preto. No título da reportagem "Serviços como vender o que o cliente não vê", a figura "serviços" é grafada em branco, "como vender" em cinza-escuro e "o que o cliente não vê", em preto. Temos, assim, uma combinação cromática entre esses gêneros textuais, que se estendem ao gênero capa (anexos, Fig. 5). O logotipo VendaMais está grafado em branco. Observa-se, nele próprio, a configuração do modo imperativo: VendaMais.

No título do encarte "Dicas de Bolso - VendaMais Hoje - Serviços", há o enunciado, topologicamente situado quase no rodapé do encarte, que expressa: "Leve na carteira e consulte sempre". Observam-se, nesse enunciado, dois verbos no imperativo: "leve e consulte". 
Nas divisões sanfonadas desse encarte, que devem ser abertas para leitura, estão os títulos compostos com iniciais do verbete "Serviços": tudo coordenado e bem arranjado visual e verbalmente. Trazemos esses títulos, que aparecem na partes frente e trás, grafados na cor verde: "S de sonho; $\mathrm{E}$ de estudo; $\mathrm{R}$ de relacionamento; V de vigilância; I de incentivo; AÇÃO, sempre; O de ouvir o cliente; S de simpatia". Cada título traz regras numeradas a seguir. Transcrevemos a primeira como exemplo, de título "S de sonho":

A imaginação é a grande arma do vendedor de serviços:

1. Desenvolva a capacidade de contar histórias, de narrar as qualidades de seu serviço de uma forma que envolva seu prospect ou cliente.

2. Narre experiências de outros clientes, abuse dos testemunhais.

3. Peça que seu prospect imagine-se usando seu serviço e as vantagens que ele pode perceber. Deixe que ele venda a idéia para si.

Grifamos em itálico para pôr em destaque o número de verbos no imperativo: um total de cinco. Extraímos os demais verbos desse gênero, que traz a recorrência isotópica de verbos no imperativo ou com valor de imperativo: "verifique; ajude; monte; visite; abuse; tenha; deixe; blinde-se; analise; adapte; melhore; verifique; atualize; traga; peça; facilite; tenha; use; demonstre; crie; altere; faça; não se permita; estabeleça; use; troque; convide-o; entenda; seja; torne-se; não tenha pressa; dê-lhe; ajude-o; entre em contato; não permita; planeje; verifique; não se permita; inove.

Observa-se a grande quantidade, num total de 46, que tecem o texto/discurso, o que pressupõe a voz firme de um sujeito a ditar regras de como fazer.

O destinador-manipulador, que remete ao enunciador, oferece ao enunciatárioleitor um valor no qual faz crer: o saber, que, ao ser adquirido, torna-o competente para ser bem-sucedido na venda de serviços. O destinatário-alvo, lembremos, é normatizado: ele espera, quer esse saber para poder-fazer. Esse conhecimento "(o saber) é sempre vendido como instrumento de vantagem competitiva", diz Hernandes (2006: 41).

Como temos aqui, novamente, imagem e valores positivos envolvidos, firmamse processos discursivos de manipulação por tentação e sedução na relação destinadormanipulador/destinatário-alvo e, assim, vemos configurada uma voz otimista com o poder e saber-fazer do destinador para levar o destinatário-alvo a querer-fazer: saber "vender bem serviços". O objeto-valor envolvido, como no texto reportagem, é o próprio saber. "Sendo assim, o saber-fazer aparece como aquilo que torna possível essa atividade, como uma competência cognitiva" (Greimas e Courtès, 1989: 388).

Ao considerar as tipologias de manipulação que envolvem esses gêneros textuais constituintes encartes pares, temos:

Tentação: Se você, vendedor, seguir as dicas aqui prescritas, será recompensado, terá mais saber para "vender bem serviços".

Sedução: Você, que já é um bom vendedor, ao ter mais saber, será melhor ainda, não é? 


\section{Prescrição e tipo textual injuntivo}

A prescrição configura, em princípio, a modalidade deôntica, já que envolve um dever-fazer de um destinador ao seu destinatário. Entretanto, ao considerar esse destinatário como alvo, que pertence a uma classe de sujeitos pré-selecionados na instância corporativa - homens e mulheres de negócios -, temos sujeitos dados como leitores-alvo ideais, aqueles que têm alto grau de saber da temática discursiva na esfera de atividade social inerente. Há, desse modo, maior relação de interdependência no ato comunicativo: enunciador e enunciatário em um universo discursivo no qual o primeiro é conhecedor da competência do segundo e, por isso, reconhecedor do saber e poderfazer deste. A relação, portanto, é de "parceria", de sujeitos que detêm valores partilhados no universo discursivo.

A prescrição ao destinatário-alvo não é, desse modo, dada como conflituosa, já que transmitida e interpretada de forma consensual. A linguagem é desprovida de ironia ou derrisão: é tecida com seriedade e com tom firme, certeiro. Temos, com esse destinatário-alvo, um sujeito receptivo e "parceiro" na troca comunicativa. O deverfazer, prescrito pelo destinador, é, desse modo, tomado pelo destinatário, sujeito interpretante, de forma estimulante e confiante. Esse destinatário tem o querer-fazer: saber mais. Nesse caso, ao tratar da estrutura modal dever-fazer, consideramos apropriada a observação de Greimas (1989: 118):

A estrutura modal do dever-fazer comporta indiscutivelmente afinidades semânticas com a do querer-fazer, a tal ponto que os estudiosos se interrogam freqüentemente a fim de saberem se não é possível - e oportuno - reduzi-las a uma única estrutura modal virtualizante. A dificuldade prende-se à escolha que será preciso operar então, quer para reduzir o dever-fazer ao querer-fazer, quer vice-versa. Os representantes da tendência psicologizante inclinar-se-ão a ver no dever-fazer do sujeito um querer (transferido) do Destinador, os que defendem a lógica interpretarão antes o querer-fazer como um dever autodestinado.

Esse dever, autodestinado, está, portanto, voltado ao S2, o destinatário dado como alvo, sujeito previamente eleito, competente, aquele que quer, pode e sabe interpretar o que S1 propõe para conseguir a competência desejada. Por isso, diz respeito a uma instância discursiva estabilizada, com sujeitos comprometidos na transferência de competência para um sujeito atualizado, pronto para agir, realizar-se. A realização de S2 é, assim, dada como plausível. Barros (2002: 53) diz que, "se na organização modal de sua competência incluem-se também o saber e/ou o poder-fazer, tem-se um sujeito atualizado ou competente, qualificado para fazer".

\section{Paixões}

Considera-se, especialmente, que o visual dos encartes pares é bem arranjado para os fins que pretende atingir: chamar a atenção do enunciatário-leitor, levá-lo à "impulsividade" para superar expectativas, vender bem serviços. Como dizem Greimas 
e Fontanille (1993: 62): "Por exemplo, a 'impulsividade' pode ser traduzida como certa associação de querer-fazer e de poder-fazer, e se descreverá como uma 'maneira de fazer"”. Esse sujeito, assim modalizado, toma essa "maneira de fazer", com "impulsividade", mas de modo confiante, já que sabe que pode fazer. Não se trata de um sujeito em conflito, desesperado, aquele que "dispõe, de certo modo, de duas identidades modais independentes, a do fracasso e da frustração, por um lado, e a da confiança e da expectativa, por outro; e a ruptura é um efeito de sua independência e de sua incompatibilidade" (Greimas e Fontanille, 1993: 68). Sobre a paixão do desespero, assim se posicionam os autores:

O desespero comporta um dispositivo modal do tipo conflitual, no que o querer-ser, de um lado, e os saber-não-ser e não-poder-ser, de outro, coabitam sem se modificar reciprocamente, contradizem-se e contrariam-se, provocando a ruptura interna do sujeito (Greimas e Fontanille, 1993: 68).

Ao considerar, nessa esfera discursiva, a corporativa, o sujeito destinatário como alvo, tem-se que esse sujeito é sempre atualizado, nunca realizado, sempre em busca de um fazer mais, superar expectativas: um sujeito modalizado pela emulação. Greimas e Fontanille (1993: 51) dizem que "o êmulo só é sujeito modal em razão do programa particular em que sua competência está engajada e colocada em questão". Assim explanam os autores esse sentimento que modaliza sujeitos:

Com efeito, a 'emulação' instaura um querer-fazer - 'tão-bem-ou-melhor-queo-outro'; mas esse querer-fazer procede aqui de um querer-ser - 'aquele-oucomo-aquele-que-fez', isto é, de uma identificação com certo modal de outrem; em outros termos, a emulação não tem por finalidade a reprodução do programa do outro, mas a da 'imagem' modal que o outro oferece ao cumprir seu programa, seja ele qual for: um 'estado de coisas', a competência de outrem, vê-se assim convertido em 'estado de alma', a imagem modal visada por ela mesma pelo sujeito da emulação (Greimas e Fontanille, 1993: 51).

O estado de alma desse sujeito-alvo, dado como êmulo, contribui para a eficácia de uma manipulação/interpretação mais produtiva, porque envolve sujeitos competentes, tanto para transmitir quanto para interpretar (destinador e destinatárioalvo). A imagem envolvida, relembremos, é positiva e não negativa. A interação é plena e harmoniosa. Considera-se, contudo, a hipótese de que esses sujeitos, na esfera de sentido e produção discursiva delimitada, têm uma relação de subordinação conjunta a um destinador-manipulador maior, que se apresenta em outra instância, construindo valores prévios: o sistema mercadológico. Esse sistema, dotado de poder-fazer, pode exercer coerção por meio de valores previamente construídos, prescrevendo um deverfazer dado como intimidativo, configurando ameaça a uma suposta não-aceitação de tais valores prévios impostos. Se configura ameaça, os valores envolvidos são negativos e o ato de manipulação por intimidação pode ser assim representado, considerando sujeitos atualizados para tornarem-se realizados: Vocês sabem que têm de ser capazes 
de tornarem-se "bons chefes" (para serem sujeitos realizados); Vocês sabem que têm de ser capazes de "vender bem serviços" (para serem sujeitos realizados).

\section{Breve Conclusão}

Comprova-se que o tipo textual injuntivo pode aparecer na tessitura de gêneros textuais de formas composicionais diferenciadas, inclusive em textos da esfera de sentido social corporativo-administrativa.

Consideramos, especificamente nos gêneros textuais aqui analisados, os constituintes de revistas impressas da esfera de sentido negócios empresariais, com sujeitos que se reconhecem e se aceitam na situação de comunicação: o enunciador tem seu enunciatário-leitor como alvo, com quem mais troca, partilha saber, de forma assimétrica, mas de modo harmônico, numa relação estreita, de confiança plena.

Por meio de textos predominantemente injuntivos observados, que se assemelham a "receitas", temos, especialmente, operações de manipulação por tentação e sedução de um sujeito atualizado, previamente reconhecido pelo saber, poder e querer-fazer.

O enunciador é conhecedor e reconhecedor da competência de interpretação de seus "ensinamentos" pelo seu enunciatário-leitor. Essa relação é, portanto, de "parceria", de engajamento de sujeitos que detêm valores partilhados no ato comunicativo e no mundo. São sujeitos semióticos que se reconhecem em uma cena enunciativa concordante, que se corporificam por meio de um modo próprio de habitar a esfera social - dá-se segundo a sintagmática das modalidades do poder, do saber e do querer, combinadas de tal modo que resultam no efeito de sentido de confiança e certeza do dito e do interpretar. Isso configura sujeitos, que, segmentados em determinada esfera de atividade social, mantêm uma relação mais aproximativa no ato comunicativo: enunciador e enunciatário (leitores-alvo ideais) em um só universo discursivo, no qual interagem.

Legitimam-se lugares de quem fala e de quem escuta, já que são sujeitos formados num ideal de corporalidade. Nessa corporalidade reflete-se e refrata-se um corpo ideológico construído discursivamente, que afirma valores numa relação estabilizada e partilhada de poder e querer saber mais para obter desempenho otimizado no mundo dos negócios.

\section{REFERÊNCIAS BIBLIOGRÁFICAS}

BARROS, Diana Luz Pessoa de. Teoria do discurso: fundamentos semióticos. 3. ed. São Paulo: Humanitas, 2002.

CHARAUDEAU, Patrick. Discurso das Mídias. Trad. Angela M.S. Corrêa. São Paulo: Contexto, 2006.

DISCINI, Norma. Comunicação nos textos. São Paulo: Contexto, 2005.

FIORIN, José Luiz. Gêneros e tipos textuais, 2004. Cópia xerogr. . O pathos do enunciatário, 2004a. Cópia xerogr. 
GREIMAS, Algirdas Julien e COURTÈS, Joseph. Dicionário de semiótica. Trad. Alceu Dias Lima et alii. São Paulo: Cultrix, 1989.

HERNANDES, Nilton. A mídia e seus truques. São Paulo: Contexto, 2006.

MAINGUENEAU, Dominique. Análise de textos de comunicação. Trad. Cecília P. de

Souza-e-Silva e Décio Rocha. 2. ed. São Paulo: Cortez, 2002.

RABAÇA, Carlos Alberto; BARBOSA, Gustavo Guimarães. Dicionário de comunicação. São Paulo: Ática, 1978. 


\section{ANEXOS}

\section{Como contratar}

$\mathrm{M}$

es chefes contratam a si mesmo, repetidas vezes. Primeiro, rocuram alguém de perfil parecido com o seu. Depois, na hora da entrevista, falam pelos cotovelos e acham a convers maravilhosa - encantaram-se consigo próprios. Mais tarde, decepcionam-se quando o contratado se revela outra pessoa. Para evitar isso, alguns procedimentos básicos (a maioria vale também para recrutamento interno ou promoção de alguém da equipe):

- Conheça o planejamento estratégico da companhia, para desenhar um perfil de profissional que se enquadre às necessidades da empresa.

- Descreva a sua necessidade atual da forma mais detalhada possivel. Até para saber se é uma só pessoa que você quer, ou três.

- Desenhe o processo, as etapas da seleção: onde você vai fazer sua busca, se vai ter ajuda externa, quantas pessoas vão entrevistar 0 candidato, quais os critérios para a escolha.

- Na hora da entrevista, fale menos que 0 candidato. Bem menos. Uns $20 \%$ do tempo é a recomendação mais geral.

- Entreviste poucas pessoas, para poder thes dar a atenção devida. Isso inclui ler atentamente o currículo antes da entrevista e anotar dúvidas a esclarecer, atender o candidato na hora marcada, de preferência numa sala de reuniōes, para não ser interrompido, preparar algumas perguntas, planejar o tempo que pretende gastar e informar seu interlocutor.

- Durante a entrevista, siga uma linha de raciocínio. Você não quer confundir o candidato.

- Varie as perguntas, entre abertas (descreva uma situação em que você lidou com um cliente difícil) e fechadas (em que você se

\begin{abstract}
formou?, o que você quis dizer com blablablá?).
- Pergunte como ele gosta de ser chefiado, quais suas

prioridades no dia-a-dia, como seria 0 chefe ideal.

- Habitue-se a relativizar os sucessos e os fracassos do candidato lembrando do ambiente em que atuou, o momento da economia.

- Há muitas bobagens escritas sobre linguagem corporal, mas, - o gastul não combina com 0 que ele está lhe dizendo (se não olha no olho, se diz ser audacioso mas se senta encolhido...), cheque suas impressões com perguntas.

- Evite pegadinhas: a imagem da empresa está sendo passada na entrevista. Quanto mais à vontade você deixar 0 candidato, melho

- Reserve algum tempo no fim da entrevista para responder às perguntas dele, mas não entre em detalhes sobre 0 cargo e 0 salário antes de fazer sua escolha. Transmita seu entusiasmo pela empresa, pelo posto vago, pelas oportunidades a ser abertas - Verifique as informações. Telefone para ex-colegas do candidato, seus chefes, instituições que possam confirmar os títulos. Avise ao candidato para quem você vai telefonar.

- Depois de feita sua escolha, negocie um bom pacote. Jamais ultrapasse os limites de bonificação que estabeleceu no começo do processo. Nunca cubra uma contraproposta do empregador do seu candidato. Mas você pode se antecipar a ela lembrando que sete em cada dez empregados que aceitam um aumento para ficar no emprego acabam saindo em menos de um ano, porque em geral as questões de fundo que geraram a insatisfação não são resolvidas. - Envie mensagens de agradecimento aos que participaram do processo. Aos finalistas, agradeça por telefone.

Fontes: The Boss's Survival Guide, Beatriz Garcia (Nicholson), Gutemberg.

de Macedo (Gutembers Consultores). Patricia Molino (KPMG). Luiz Carlos Cabrera (PMC)
\end{abstract}

Fig. 1 - ed. 765 (EXAME, 1\%/05/2002, p. 43)

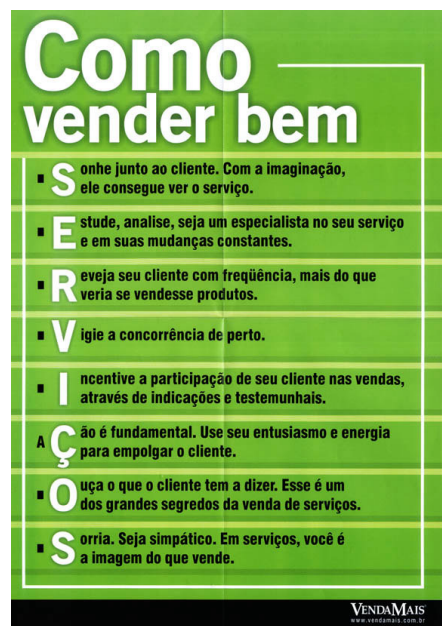

Fig. 2 - Encarte pôster, inserido na ed. 147, revista VendaMais, de julho de 2006. 


\begin{tabular}{|c|c|c|c|}
\hline ACQino, sempre & Ode ouvir o cliente & Sule simpatia & Emais: \\
\hline $\begin{array}{l}\text { Venda de serviços é um processo. } \\
\text { Entáo: } \\
\text { 1. Use seu entusiasmo para encantar o } \\
\text { cliente. Demonstre, em sua voze e } \\
\text { linguagem corporal, o quanto você } \\
\text { acredita no que vende. } \\
\text { 2. Crie uma proposta de valor dinâmi- } \\
\text { ca. A cada nova caracteristica, a } \\
\text { cada novo uso descoberto pelo } \\
\text { cliente, altere sua apresentação de } \\
\text { vendas. Seu serviço e algo vivo. } \\
\text { Faça com que sua apresentação e } \\
\text { proposta acompanhem suass trans- } \\
\text { formaçōes e a maneira como o } \\
\text { cliente o vê. }\end{array}$ & $\begin{array}{l}\text { A opinião do cliente é importante em } \\
\text { toda a venda, ainda mais em serviços: } \\
\text { 1. Não se permita sair da frente do } \\
\text { cliente sem descobrir algo sobre ele ele } \\
\text { ou sobre a maneira como ele utiliza } \\
\text { seu serviço. } \\
\text { 2. Estabeleça uma troca de idéias fre- } \\
\text { qüente com ele. Use informativos, } \\
\text { troque e-mails, convide-o para lan- } \\
\text { çamentos. } \\
\text { 3. Entenda a maneira como diferentes } \\
\text { públicos vêem seu serviço. }\end{array}$ & $\begin{array}{l}\text { Você é a imagem de seu serviç̧o: } \\
\text { 1. Seja simpático e solicito, sempre, } \\
\text { principalmente se seu cliente não } \\
\text { puder ver e tocar o que você vende. } \\
\text { Torne-se a melhor imagem de seu } \\
\text { serviço. } \\
\text { 2. Não tenha pressa de sair da frente } \\
\text { do cliente ou prospect. Dê-lhe todo } \\
\text { apoio, ajude-o a tomar a melhor } \\
\text { deciaso. } \\
\text { 3. Entre em contato logo após a aquisi- } \\
\text { çăo do serviço. Não permita que o } \\
\text { cliente se sinta abandonado. }\end{array}$ & $\begin{array}{l}\text { 1. Planeje sempre sua proxima venda. } \\
\text { 2. Verifique sempre se seu cliente está } \\
\text { satisfeito com seu serviço. Não se } \\
\text { permita ser surpreendido com a } \\
\text { noticia de que ele foi para a con- } \\
\text { corrência. } \\
\text { 3. Inove constantemente. }\end{array}$ \\
\hline WwW VENDAMAIS. com.BR & WWW VENDAMAIS COM.BR & WWW VENDAMAIS COM.8R & WwW.VENDAMNAS. COM.8R \\
\hline
\end{tabular}

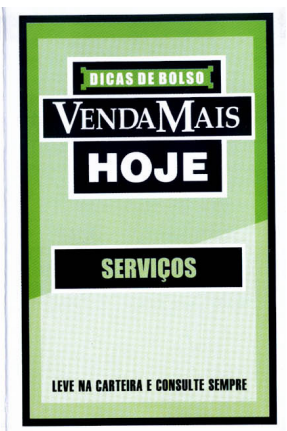

Fig. 3 - Encarte brinde de bolso (frente), inserido na ed. 147, VendaMais, de julho de 2006.

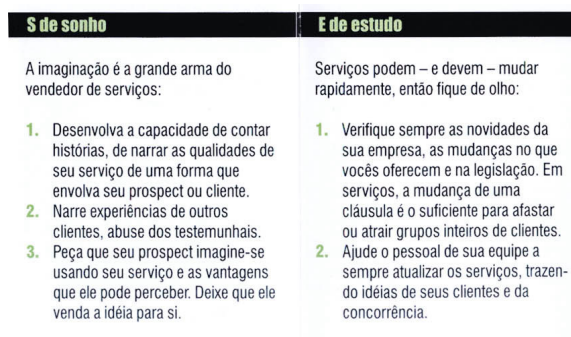

\section{Rite relacionamento Vule vigilância}

Mais do que em outros tipos de venda, é importante estar sempre ao lado do cliente:

1. Monte sua agenda de forma que você sempre tenha espaço para vistar clientes antigos.

Visite seus clientes, não necessariamente para vender. Em muitos tipos de serviço, você é a única lembrança fisica que 0 cliente tem de ter adquirido 0 que você vende.

Da mesma forma, abuse de comunicaçōes, clubes de fidelidade, cartoes de congratulaçoes e outros. Ele
Tenha sempre um olho no que a concorrência faz. Em serviços, ela tende a ser bem mais dinâmica.

Deixe muito claro o que você tem de diferente da concorrência, sempre. Blinde-se contra qualquer ataque.

Analise de perto náo só o preço, mas a mudançă nas condicōes. formatos e novos serviços. Adapte as melhores idéias, melhore 0 que elas fazem.

A cada movimento da concorrência verifique se as vantagens que vocé mas Atualize seu conhecimento.

\section{Itie incentivo}

Traga seus clientes para perto de você. Eles são uma imensa vantagem na vend de serviços:

1. Sempre peça testemunhais e indicaçōes, nảo apenas na primeira venda, mas nas outras também.

. Facilite a açáo de seus clientes. Tenha sempre em mao modelos de cartas em que o cliente acrescentaria algumas palavras de seu testemunhal ou vantagens exclusivas para quem in

Fig. 4 - Encarte brinde de bolso (trás) inserido na ed. 147, VendaMais, de julho de 2006. 


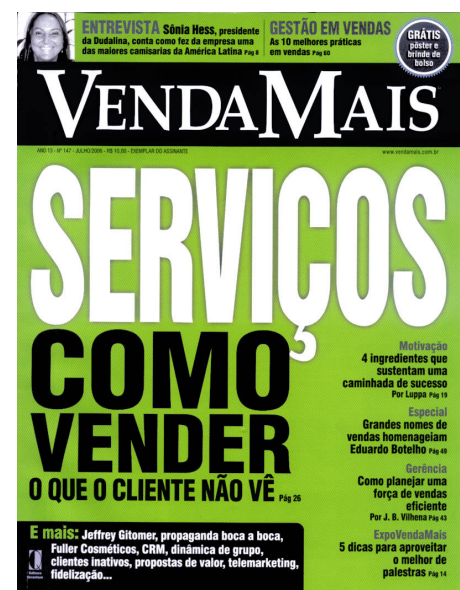

Fig. 5 - Capa ed. 147, revista VendaMais, de julho de 2006.

\section{Como citar este artigo:}

MEN, Cleonice. Tipo textual injuntivo: exemplos em revistas impressas de negócios. Estudos Semióticos, Número 3, São Paulo, 2007. Disponível em <www.fflch.usp.br/dl/semiotica/es>. Acesso em "dia/mês/ano". 